If the first of these two questions is answered in the affirmative, the working body created and necessary means secured, then the details of the plan can safely be left for that body.

The Royal Society gave as the date, when the work ought to be in shape to begin, the year 1900 ; and I think that year is none too far away, as the necessary preparations, as a matter of course, will take some years.

It was proposed, and specially by Mr. G. Brown Goode, in his very full and suggestive article, that an International Congress of Science be organized, something of the same character as the American and British Associations for the Advancement of Science. I agree fully with this proposal of an international congress. But I would make its scope more narrow and to the point, an International Congress of Bibliography. And to prepare for this, I would suggest that there be started right here an organization committee to consult with interested bodies and persons both in America and in the European countries. Will the Editor of ScIEnce take this matter in his hands and call such a committee?

Aksel G. S. Josephson.

LeNox LIbRary, New York.

\section{A CARD CATAlogue OF SCIENTIFIC LITERATURE.}

THE valuable papers that have appeared in Scrence on the practicability of a card catalogue of scientific literature have awakened a deep interest in the subject among those who feel how desirable a work of this kind would be to each individual worker in the field of science. Already an immense amount of scientific literature has accumulated which needs to be brought together in such a manner as to be readily accessible to the investigator, and, when we consider the rate at which it is increasing, the necessity for adopting and putting into operation some plan by which the users of scientific literature may be able to find all that has been written upon a given subject pertaining to science becomes strikingly apparent.

The writer has been engaged in preparing a bibliography and index of certain subjects for several months past, and the desire that the results and such tentative deductions as may be drawn from them may be added to our knowledge of the actual possibilities of a catalogue of scientific literature, and that other workers in this line may be induced to give us their experience, represents the object of this communication. The work just referred to was begun without previous training in this special line and with somewhat indefinite ideas as to what might be accomplished in the time that could be devoted to it. The opinions that have been formed during its progress, in their bearing on the present discussion, will first be stated before describing in some detail the scope and character of the work that is now being carried on.

1. The card catalogue, it has been said, has its limitations. This must be evident to every one when it is considered that such a catalogue as has been recommended to the Royal Society by the Harvard University Committee will extend over a series of years and must inevitably become bulky and unwieldy even when applied to but a single branch of science. Then, too, something more than a bibliography is becoming necessary. This is readily seen when one considers the time and labor expended in frequently running through a long list of titles of papers in order to find what has been written on a given subject.

2. Such a work should be published in book form after the close of each year and contain a bibliographic catalogue and a subject index. It is unnecessary that the indexing should be carried to the extreme, but simply to gather together under each special division of every branch of science 
those papers which bear on that particular subject. It has been urged that none but the expert or specialist should undertake subject indexing. It is desirable that the scope and arrangement of the subject index of each branch of science should be determined by specialists in that particular branch. But, since it is not possible nor even desirable to go to the extreme in indexing, it seems quite probable that a general subject index of all the principal subdivisions of each branch of science can be accurately arranged on a previously determined plan, by one who has only a general knowledge of the principles on which each of the branches upon which he is working is based.

3. International coopperation in the past has not been of such a character as to fill one with confidence that it would successfully manage a work of such magnitude. The scope and plan of the work should be determined by an international committee, but the responsibility for the accuracy and prompt publication of the matter should be as limited as possible. An international committee might be selected to determine the scope and arrangement of the work, the language or languages in which it is to be printed, the person or persons who are to be in charge of its preparation and responsible for its accuracy and completeness, and to adopt a plan for raising the necessary funds. One person might be selected from each of the several European countries and from the United States to prepare a bibliography and index, on this predetermined plan, of all scientific literature published in their own country during each year ; this manuscript to be forwarded to the central office and there examined and arranged in final form, and each person to receive compensation and credit for the individual work performed. To carry out such a plan involves a great amount of careful, painstaking and laborious work, and its success would largely depend on the proper selection of individual workers, and on the coöperation with them of the scientific world in general.

4. It seems quite necessary that a concise synopsis of the contents of each paper should be made and form a part of the bibliography. This should be printed in the language in which the paper is written, and should be translated into English or French or both. This adds greatly to the work of preparation, but it is the only way to make it of practical use to the hundreds, possibly thousands, who would use such a work.

5. It should not only be published as a whole, but should be so prepared as to be separated into different parts to be distributed as separates for the use of those who do not care to subscribe for the whole work. By determining the arrangement of the index before beginning the perusal of the literature, on one side of the catalogue card could be written the entry for the bibliography, and on the reverse side the subdivisions of the index under which the paper properly belongs. Copies of these cards could be made, and from these a bibliography and index of any branch or a number of branches of science could be published separately with a minimum amount of labor and expense.

The work which has been heretofore referred to as being carried on by the writer comprises a bibliography and index of North American geology, paleontology, petrology and mineralogy and is to be published as a bulletin of the United States Geological Survey. It is intended as a continuation of the previous publications of the Survey of the Record of North American Geology, but the scope of the work and its arrangement have been materially changed. The first number contains a record of papers published during 1892 and 1893 and is now in press. The work for the year 1894, it is expected, will be distributed before the close of the present year, and the manuscript for 
1895 will be ready for the printer shortly after its close.

It is divided into two parts: a bibliography and an index. The bibliography is arranged alphabetically by authors' names and contains the titles of each paper, place of publication, references to abstracts and reviews, and a brief summary of the contents. The entries are numbered from 1 to something over 1100 and are used for index reference. The index of the four subjects is published as a whole and is arranged alphabetically. Its geographic arrangement is by States and Territories of the United States and the other political divisions of North America. The geologic subdivisions are those of the different geologic periods and dynamic, economic, glacial and physiographic geology. The papers relating to economic geology are arranged by condensed titles of papers under the different geographic subdivisions which they describe, and there is also given a list of the useful minerals and ores described. Under mineralogy is given the condensed titles of papers and a list of minerals described. Petrology is divided geographically by the States and countries in which the rocks described occur and by a list of rocks described. Paleontology is subdivided by the different geologic periods and a list of genera and species described. In each of the lists of ores, minerals, rocks and genera and species the paper in which they are described is referred to by author's name and number of the entry in the bibliography. These represent the main features of the index:

In making up the bibliography the library catalogue card is used (size $4 \frac{1}{2} \times 6 \frac{1}{2}$ inches). On one side is written the entry that appears in the bibliography, and on the other the subdivisions of the index under which the paper is to be listed. In this manner all the information in regard to each paper is assembled on one card. Thus the indexing can be determined on while the paper is still in hand, and, as soon as the bibliography is complete, the task of making up the index can be easily and rapidly accomplished.

The following specimen card illustrates the plan:

FACE OF CARD.

HILL (Robert T.), Geology of parts of Texas, Indian Territory and Arkansas adjacent to the Red River. Geol. Soc. Am., Bull., vol. 5, pp. 297-338, pls. 12-13, figs. 1-4.

Describes the physiography of the region. Gives a list of the Cretaceous, Tertiary and Pleistocene formations and their subdivisions, whose outcrops at different localities are described. Gives lists of fossils found at certain horizons, discusses the oscillations of land and sea, and includes the author's conclusions as to the Cretaceous section of the region. Plate 12 contains a geologic map and cross sections.

BACK OF CARD.

Texas, Arkansas, Indian Territory, Cretaceous, Eocene, Pleistocene, Paleontology (Cretaceous), Physiographic geology.

The work has been conducted along with other office work, and hence only an approximation as to the length of time required to complete a year's bibliography of this kind can be made. It is believed that from four to five months' time of one person will be required to examine the literature, prepare the manuscript and read the proof. With skilled clerical assistance much more could be accomplished in the same time.

\section{U. S. Geological Survey.}

F. B. WeEks.

\section{VOLCANIC DUST.}

SEveral notices of volcanic dust have appeared recently in Scrence. It may be interesting, perhaps, to some of the readers of ScIEnce to learn that a large deposit of of volcanic dust occurs in central Kansas, in $\mathrm{McPherson}$ Co., just north of the watershed between the Smoky Hill and Little Arkansas, and in the great depression extending from Salina to the Little Arkansas. 